\title{
Fruit splitting in 'Nova' hybrid mandarin in relation to the anatomy of the fruit and fruit set treatments
}

\author{
A. Garcia-Luis", A.M.M. Duarte, I. Porrae, A. Garcia-Liciónb, \\ J.L. Guardiolaa \\ ${ }^{a}$ Departamento de Biologia Vegetal, Universidad Politécnica de Valencia, 46020 Valencia, Spain \\ ${ }^{b}$ Centro Regional de Investigaciones Agrarias, 30150 La Alberca, Murcia, Spain
}

\begin{abstract}
Fruit splitting in the mandarin orange cultivar 'Nova' is related to the presence of an open stylar end in the fruit. This opening arises from a cavity present at the base of the style, and is formed in a variable proportion of fruits. The cells at the bottom of this style cavity form a rind-like tissue which develop into a navel structure. The size of this navel is larger in open-stylar end bearing fruits and, accordingly, in split fruit. The number of split fruit per tree is unrelated to the number of fruit set. The application of gibberellic acid ( $\mathrm{GA}_{3}$ ) has a variable effect on set and splitting depending on its timing. This hormone increases fruit splitting when applied at flowering, but reduces it when applied shortly after the end of the June drop. It has only a minor effect on fruit set.
\end{abstract}

Key words: Citrus reticulata X 'Orlando' tangelo; Fruit navel; Fruit splitting; Gibberellins

\section{Introduction}

Fruit splitting is a physiological disorder of citrus fruit which is considered to be caused by the pressure of the rapidly expanding pulp on the peel (Erickson, 1968). It has been described in oranges, particularly in cultivars of the navel group such as 'Washington' (Erickson, 1968; Lima and Davies, 1984a ), I'lavelina' (De 
Cicco et al., 1988; Ruiz and Primo Millo, 1989) and 'Skaggs Bonanza' (Monselise et al., 1986), as well as in 'Valencia' (Bar-Akiva, 1975). Particularly sensitive to this phenomenon are several mandarin hybrids such as 'Murcott', 'Ellendale', Niva' and 'Nova' (Monselise et al., 1986; Ruiz and Primo Milo, 1989; Rabe et al., 1990; Goren et al., 1992; Goldschmidt et al., 1992). In these cultivars, fruit drop caused by splitting may represent as much as $60 \%$ of the final yield, thus causing severe economic losses.

The extent of fruit splitting depends markedly on the year, and a climatic influence has been suspected. However, little is known on the morphological characteristics of the fruit and the internal conditions of the tree in relation to this phenomenon. Lima and Davies (1984c) reported a bigger fruit weight and stylar end aperture in split compared with healthy navel oranges. De Cicco et al. (1988) found an increase in splitting in Navelina' oranges as the longitudinal/transverse diameter ratio of the fruit decreased. In the present report we have related the incidence of splitting in the mandarin hybrid 'Nova' to crop load, fruit size and the anatomical development of the fruit. The effect of several fruit set treatments and post June drop hormonal applications on this disorder have been evaluated.

\section{Materials and methods}

\subsection{Plant material and orchard management}

The experiments and observations were carried out during 2 consecutive years in two orchards of 'Nova' hybrid mandarin (Citrus reticulata X 'Orlando' tangelo) located at Castellón and Murcia. In both plots, the trees ( 8 years old at the beginning of the experiment), were virus free. The rootstock at Murcia was Cleopatra mandarin. In the Castellón plot, the trees were grafted onto Troyer citrange and interplanted with trees on sour orange ( Citrus aura ntium L.) rootstock. Both orchards were watered as needed with non-saline water (300-500,u-mhos ) using a drip irrigation system. The amount of water applied was adjusted according to the evaporation from a class A pan. The soil was a sandy clay; the limestone content of the soil was $12 \%$ at Murcia and $26 \%$ at Castellón.

\subsection{Experimental design}

The influence of different treatments on set, yield and splitting was determined in four experiments as follows.

\subsubsection{Castellem 1991}

A $4 \times 3$ factorial design aiming to show the effect of four fruit setting treatments and three levels of calcium nitrate applications was followed. Each combination was replicated three times using a randomised block design, each replicate consisting of four trees. Thus, the values for the fruit setting treatments were the means of 36 trees. 
The following fruit setting treatments were tested: no treatment (control); gibberellic acid $\left(\mathrm{GA}_{3}\right)$ at $10 \mathrm{mg} 1{ }^{1}$; benzylaminopurine (BA) at $20 \mathrm{mg} 1-1$; $\mathrm{GA}_{3}+\mathrm{BA}$ at $10 \mathrm{mg} \mathrm{1-}^{1}$ and $20 \mathrm{mg} \mathrm{l}$, respectively. These hormones, along with a non-ionic wetting agent (alkylpolyglycol ether, $100 \mathrm{mg}^{-1}$ ), were applied on 13 May at full bloom with a hand-gun sprayer until run-off. Three litres of solution per tree were used. Calcium nitrate $(2 \% \mathrm{w} / \mathrm{v})$ was applied at three levels: none, applied once (15 July) and applied twice (15 July and 16 August). The application system and the wetting agent used was as described above.

\subsubsection{Castellón 1992}

A $2 \times 2 \times 2 \times 2$ factorial with four replications of four trees each was followed using a randomised block design. The effects tested were the fruit set treatment $(0$ and $10 \mathrm{mg} \mathrm{1-}{ }^{1} \mathrm{GA}_{3}$ ), a $\mathrm{GA}_{3}$ application at the end of the June drop (12 June; 0 and $20 \mathrm{mg} \mathrm{1-}{ }^{1} \mathrm{GA}_{3}$ ), a $\mathrm{GA}_{3}$ application in late July (23 July; 0 and $20 \mathrm{mg} \mathrm{1-1}$ $\mathrm{GA}_{3}$ ) and a $2 \%$ calcium nitrate application (none or sprayed twice in June and July). The fruit set spray was applied on 29 April at full bloom. The treatment details were as described for the Castellón 1991 experiment. In this experiment, the values for the fruit setting treatments are the means of 128 trees.

\subsubsection{Murcia 1991}

Six fruit set treatments were evaluated using three replications of ten trees each, in a randomised block design. The treatments tested were: no treatment (control); $\mathrm{GA}_{3}$ at 10 or $20 \mathrm{mg} \mathrm{1-}$; $\mathrm{BA}$ at $20 \mathrm{mg}^{1-^{1}} ; \mathrm{GA}_{3}+\mathrm{BA}$ at $20 \mathrm{mg}^{1-}{ }^{1}$ each; $\mathrm{GA}_{4,7}+\mathrm{BA}$ at $20 \mathrm{mg} \mathrm{1-}{ }^{-}$each. The application was performed on $20 \mathrm{May}$ at the end of petal fall. The other conditions were as in the Castellón 1991 experiment. Ten litres of solution per tree were necessary, owing to the greater size of the trees in this experiment.

\subsubsection{Murcia 1992}

The experimental lay-out was similar to that of the previous year. The fruit set treatments were applied on 19 June.

\subsection{Fruit set and splitting determinations}

The split fruit was counted and removed periodically from the tree starting in late August until the end of the splitting process. The fruit of the replicates was harvested separately, weighed to the nearest $0.1 \mathrm{~kg}$ and the mean fruit weight determined from a random sample of 400 fruits. From these figures the number of harvested fruits was calculated. The number of split fruit was added to this figure. In this way we obtained the amount of fruit set, i.e. those fruits which persisted on the tree in late July, at a time when the June drop had already ceased and before splitting had started. The time course of fruit growth was determined when appropriate by measuring the equatorial diameter of random samples of 25 fruits each. 
Fruit characteristics at harvest were determined separately for each replicate from random samples of 25 fruits each.

\subsection{Anatomical determinations}

The flower and fruit samples were cut with the freezing microtome and stained with Schiff's reagent or with iodine green carmin (Johansen, 1940).

\subsection{Statistical analysis}

The results were subjected to a full analysis of variance and partitioned into the main components and their interactions. Mean separations were performed when appropriate using a multiple range test. A multiple regression analysis was carried out to determine the relationship among parameters.

\section{Results}

\subsection{Fruit splitting in relation to crop load}

Fruit set was affected both by the orchard and the year. It was higher in 1992 than in 1991, and it was higher in Castellón than in Murcia in both years (Table 1). No relationship was found between the number of split fruit and crop load. In Castellón, the number of split fruit was highest in 1992, the high-yield year. In contrast, the number of split fruit in Murcia was very small in 1992. When the number of split fruit in both orchards was compared, it was highest in Murcia in 1991 and in Castellón in 1992.

Within an orchard, there were marked differences among trees in the incidence of fruit splitting. As the number of split fruit was unrelated to fruit set, the percentage of splitting decreased as fruit load increased (Fig. 1). The inverse relationship between the percentage of splitting and crop load was tightest when the yield was low.

Table 1

Fruit set and splitting in 'Nova' hybrid mandarin at the two experimental sites during the 2 years of the experiment

\begin{tabular}{lllrll}
\hline Site and year & $\begin{array}{l}\text { Fruit set } \\
(\text { no. per tree) }\end{array}$ & Fruit splitting & & $\begin{array}{l}\text { Yield } \\
\text { (kg per tree) }\end{array}$ & $\begin{array}{l}\text { Fruit weight } \\
\text { (g) }\end{array}$ \\
\cline { 3 - 4 } & & No. per tree & $\%$ & & \\
\hline Murcia 1991 & $456+9$ & $98 \pm 14$ & 21.5 & 38 & 107 \\
Murcia 1992 & $677 \pm 13$ & $9 \pm 2$ & 1.3 & 80 & 120 \\
Castellán 1991 & $571 \pm 16$ & $68 \pm 9$ & 11.9 & 59 & 118 \\
Castello:5n 1992 & $821 \pm 23$ & $96 \pm 10$ & 11.7 & 65 & 90 \\
\hline
\end{tabular}




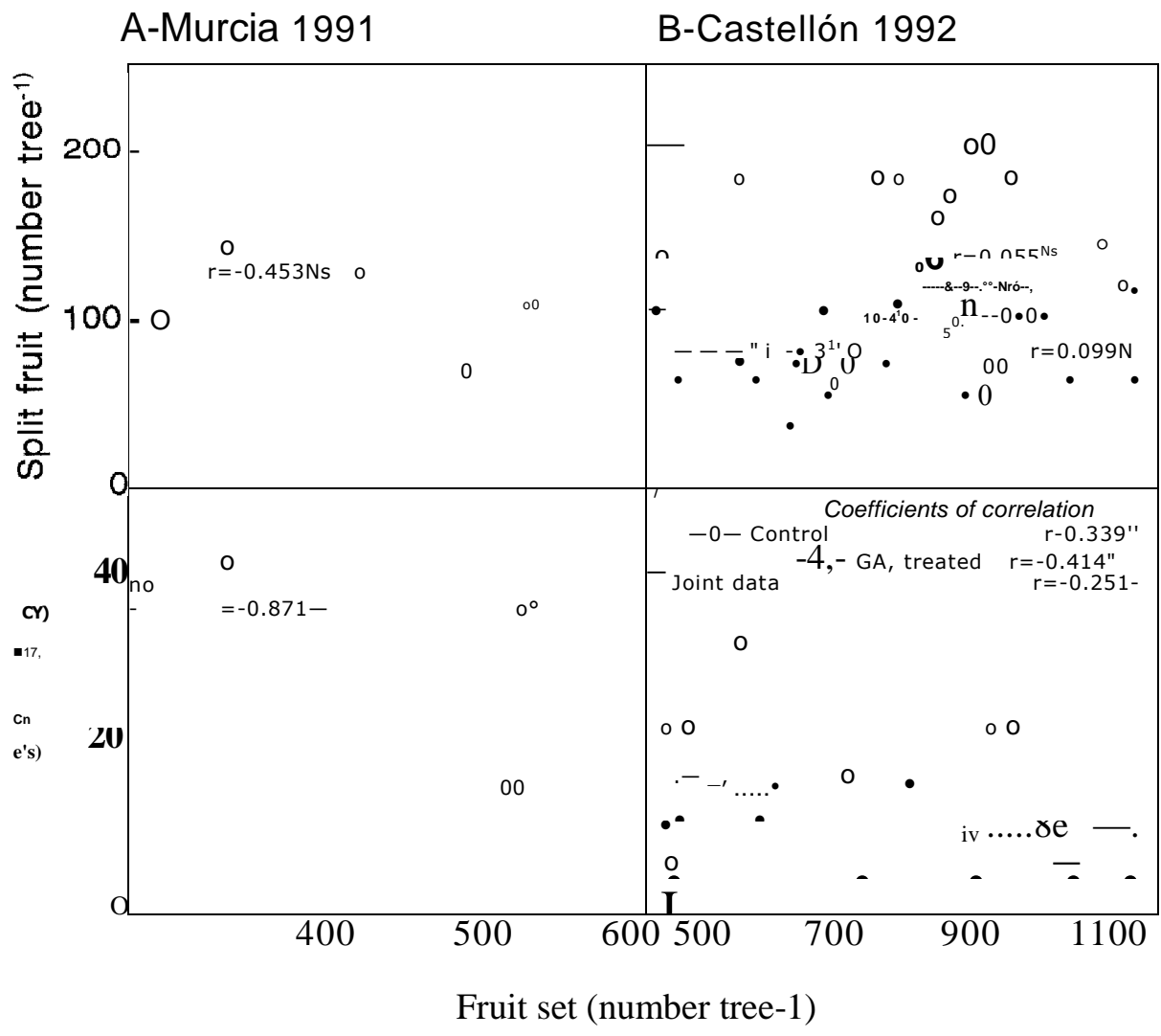

Fig. 1. The relationship between fruit set and splitting in 'Nova' hybrid mandarin at two experimental sites. (A) Murcia 1991, values are means of ten trees. (B) Castel\& 1992: •, trees sprayed with $10 \mathrm{mg}$ $1-^{-1} \mathrm{GA}_{3}$ on $23 \mathrm{July} ; 0$, unsprayed controls. Values are means of four trees.

\subsection{Fruit splitting in relation to fruit growth and size}

Splitting started in early August, but most of the fruit split during September and October, 4-6 months after full bloom (Fig. 2). During this time the increase in fruit diameter proceeded at a maximum and nearly constant rate. The time course of splitting showed marked differences among experiments (Table 2), with a maximum value either in September (Castellón 1991) or in October (other experiments). The method we followed in the determination of fruit growth prevented us from determining whether these maxima of splitting resulted from a transient increase in the rate of fruit growth. The application of $\mathrm{GA}_{3}$ at full bloom (see below) increased the number of fruits which split in September and early October (Fig. 2(B)).

Splitting was unrelated to fruit size at harvest (Table 1). The number of split fruit was very small in Murcia in 1992, when fruit size was highest. The opposite 

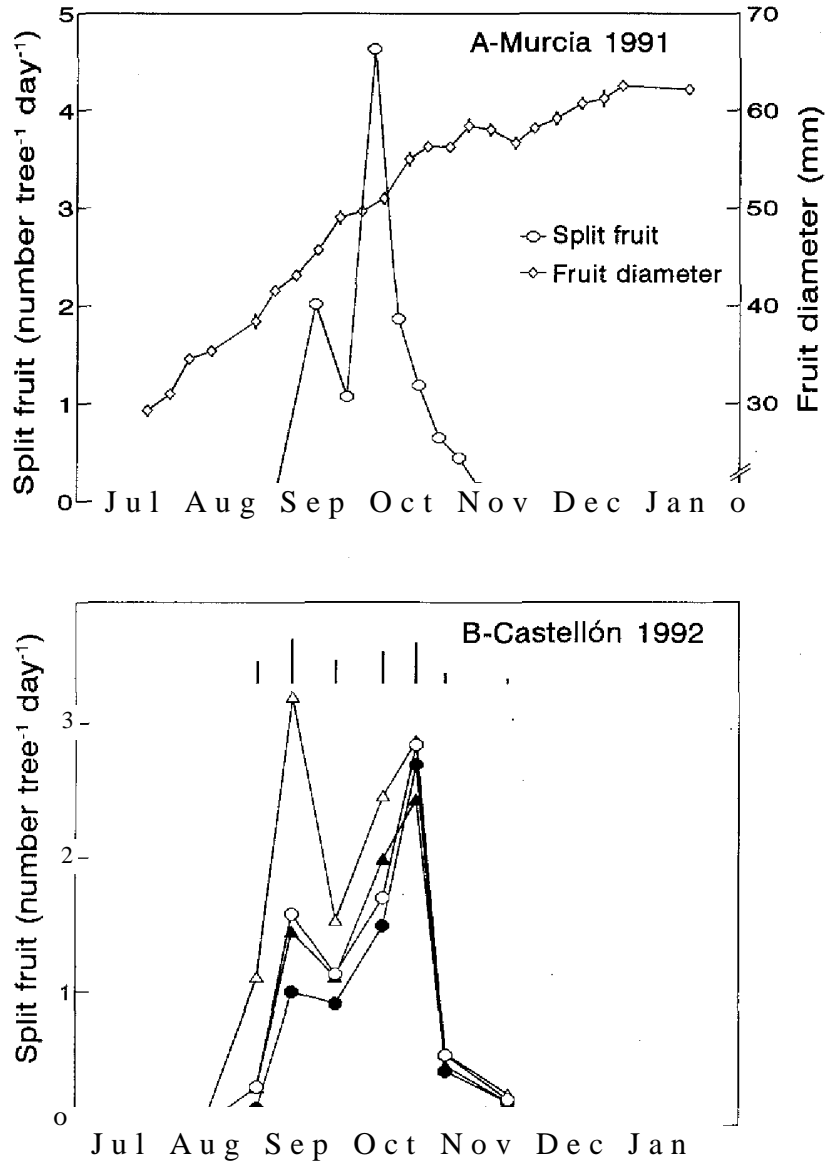

Fig. 2. (A) The time course of fruit splitting and fruit equatorial diameter at Murcia in 1991. (B) The time course of fruit splitting at Castellón in 1992 in untreated control trees (circles) and in trees

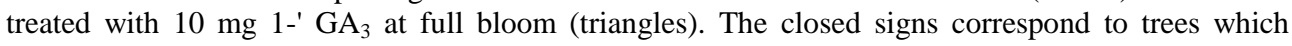
received a $10 \mathrm{mg} \mathrm{l}{ }^{\prime} \quad$ spray on 23 July. The standard errors are shown as vertical bars.

Table 2

Number of fruit split per tree and percentage of total splitting (in parentheses) in different months

Site and year

Fruit splitting

\begin{tabular}{lcrl} 
& September & October & November \\
\hline Murcia 1991 & $29(28)$ & $74(70)$ & $2(2)$ \\
Murcia 1992 & $1(10)$ & $8(80)$ & $1(10)$ \\
Castellón 1991 & $38(55)$ & $22(32)$ & $9(13)$ \\
Castellón 1992 & $31(32)$ & $60(63)$ & $5(5)$ \\
\hline
\end{tabular}


was found in Castellón, in which splitting was highest in 1992 while fruit size was smallest. This circumstance was confirmed by the low coefficients of correlation between the number of fruit split per tree and fruit weight, within experiments, which ranged between 0.124 and 0.048 (data not shown).

Fruit shape and peel thickness at harvest were unrelated to differences in splitting among experiments. The values for peel thickness at the equator of the fruit and the diameter to height ratio of the fruit in the Murcia orchard were respectively $3.18 \pm$ $0.05 \mathrm{~mm}$ and $1.14 \pm 0.008$ in 1991 , when $21.8 \%$ of the fruit split. These values did not differ from those found in 1992, a low splitting year $(3.21 \pm 0.04 \mathrm{~mm}$ and $1.15 \pm 0.006$, respectively).

\subsection{Fruit splitting in relation to the anatomy of the fruit}

The style of 'Nova' has a well developed central cavity which results in the formation of a stylar end aperture in the centre of the stylar scar in a variable proportion of fruits (Fig. 3). The epidermis at the bottom of this cavity proliferates, forming a rind-like tissue in which oil glands, chlorophyll and, in later stages, carotenoids are present (Fig. 4). This navel structure develops shortly after flower opening and its final size varies widely. In most cases it is limited at the stylar end of the fruit and its width ranges from 2 to $12 \mathrm{~mm}$. In the fruits without stylar end aperture, this tissue, always present, is concealed in the inside (Fig. 5). In a small number of fruits this tissue proliferates deep inside the fruit, with the tissue protrusions eventually reaching the calyx zone (Fig. 5).

Splitting usually started at the stylar region of the fruit. Only in a small proportion of fruits, which split late in development (during November and December), did splitting start at the equatorial region. The first symptom of splitting was the loss of chlorophyll in the fruit peel around the stylar scar, which was shortly followed by the formation of small longitudinal cracks which rapidly increased in size as the fruit grew larger (Fig. 6).

Fruit splitting was closely related to the presence of the aperture in the stylar scar as well as to the size and development of the navel tissue (Table 3). In a random sampling performed on 14 October, most of the split fruit (86\%) had an open stylar end, which was only present in $8 \%$ of non-split fruit. The split fruit either had a larger navel than the non-split fruit or, alternatively, the navel was senescent, as shown by the loss of chlorophyll and accumulation of carotenoids. At harvest (15 January), $10 \%$ of the fruit had a stylar aperture and the navel was visible (Fig. 7). A few of these fruits showed the initial stages of splitting. Fruits with an open stylar end had a bigger navel tissue than fruits without the stylar end aperture (Table $3)$.

\subsection{The effect offruit setting treatments on set and splitting}

The application of $\mathrm{GA}_{3}$ at full bloom increased fruit splitting without having any effect on fruit set (Table 4). Differences in splitting between the control and the $\mathrm{GA}_{3}$-treated trees were similar for both years, but these differences were only 
statistically significant in 1992 . Values for this year are the means of a larger number of trees (128) than for 1991 (36), and this decreased the experimental error. The increase in splitting due to the application of $\mathrm{GA}_{3}$ was significant until mid October (Fig 2 (B ) ). Afterwards, the rate of splitting was identical for control and $\mathrm{GA}_{3}$-treated trees.

The other hormone treatments applied at full bloom had no effect on set or splitting (Table 4). The fruit setting treatments performed at the end of petal fall (Murcia experiments) had no effect on set or splitting (data not shown).

\subsection{The effect of post-bloom $\mathrm{GA}_{3}$ applications on set and splitting}

The application of $\mathrm{GA}_{3}$ during the last stages of June drop (12 June) increased the number of fruit set without affecting the number of split fruit (Table 5). The differences in the number of fruit set between the untreated and the GA3-treated trees were close to statistical significance $(P>0.85)$. The application of $\mathrm{GA}_{3}$ in late July, after the end of the June drop, reduced the number of split fruit, without having an effect on fruit set (Table 5). Accordingly, this $\mathrm{GA}_{3}$ application resulted in a reduction in the splitting percentage. The effect of the July $\mathrm{GA}_{3}$ application on splitting was very marked during late August and September, and it decreased afterwards (Fig. 2 (B ) ). After mid October, the rate of splitting was identical for

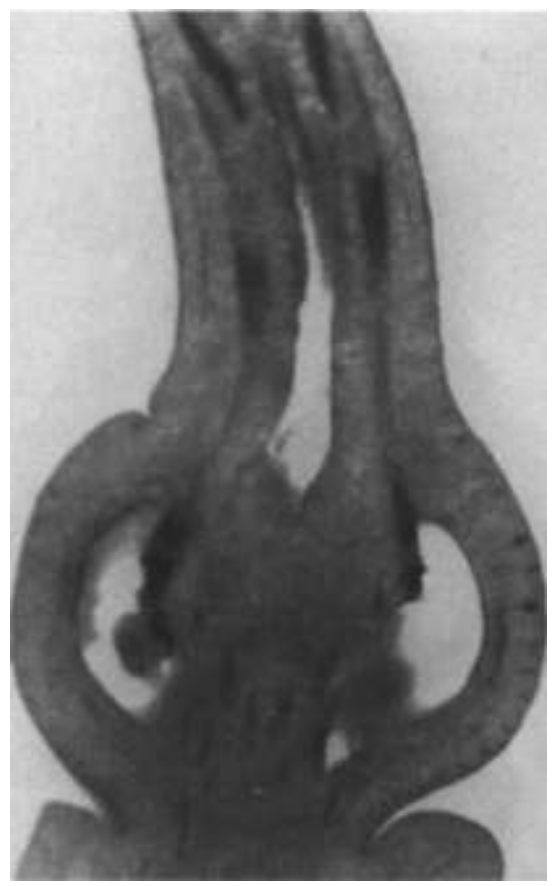



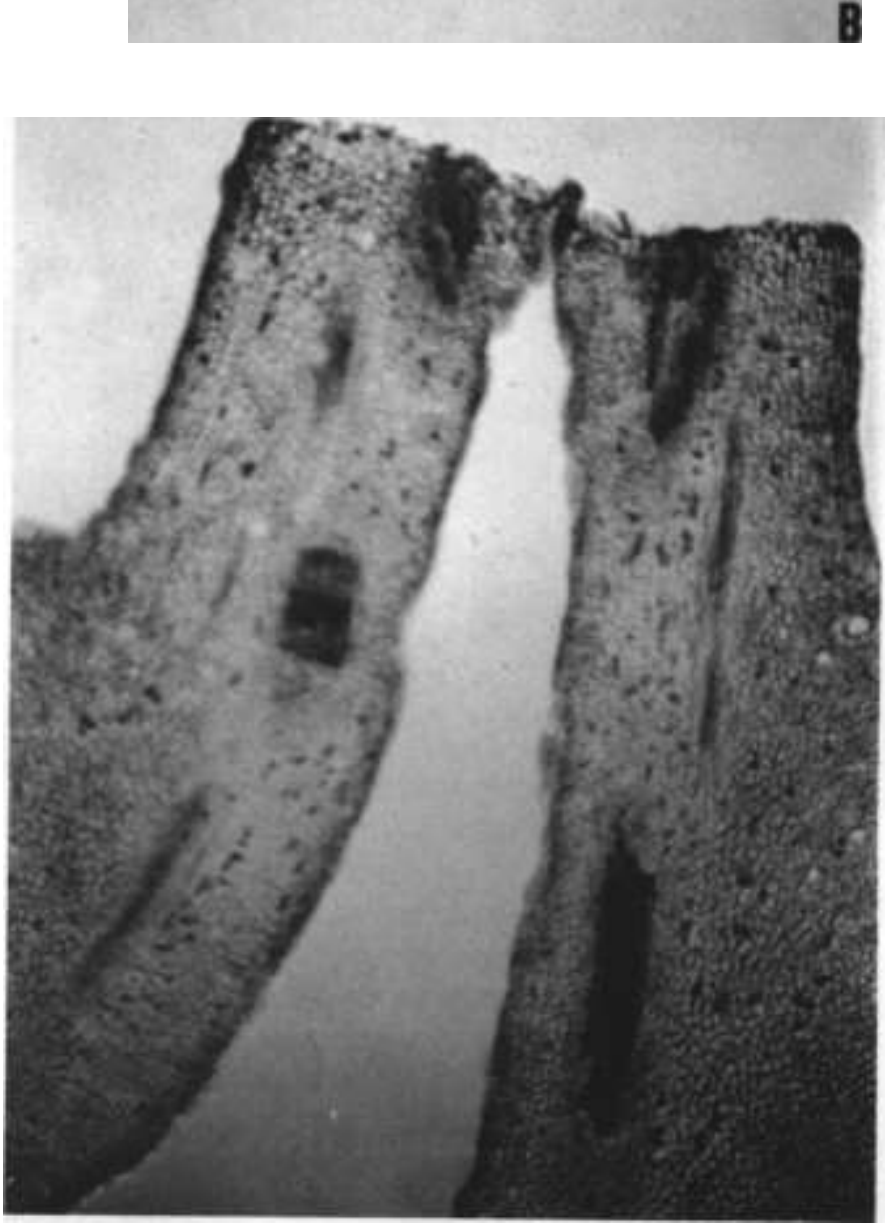

Fig. 3. (A) Longitudinal section of a flower showing the central cavity at the base of the style. (B) The abscission of the style occurs immediately above this cavity or at its upper edge.

the control and the July $\mathrm{GA}_{3}$-treated trees. The analysis of variance showed an additive effect on splitting of the $\mathrm{GA}_{3}$ applications at bloom and in late July, those trees receiving both applications having the same rate and time course of fruit splitting as the untreated controls (Fig. 2(B ) ).

The application of $\mathrm{GA}_{3}$ at both dates, June and July, reduced fruit splitting but also fruit set. As a consequence, the amount of fruit harvested was smaller for those trees treated twice with $\mathrm{GA}_{3}$ than for those receiving a single post-bloom $\mathrm{GA}_{3}$ spray, either in June or in July $(P>0.95$; Table 5). 

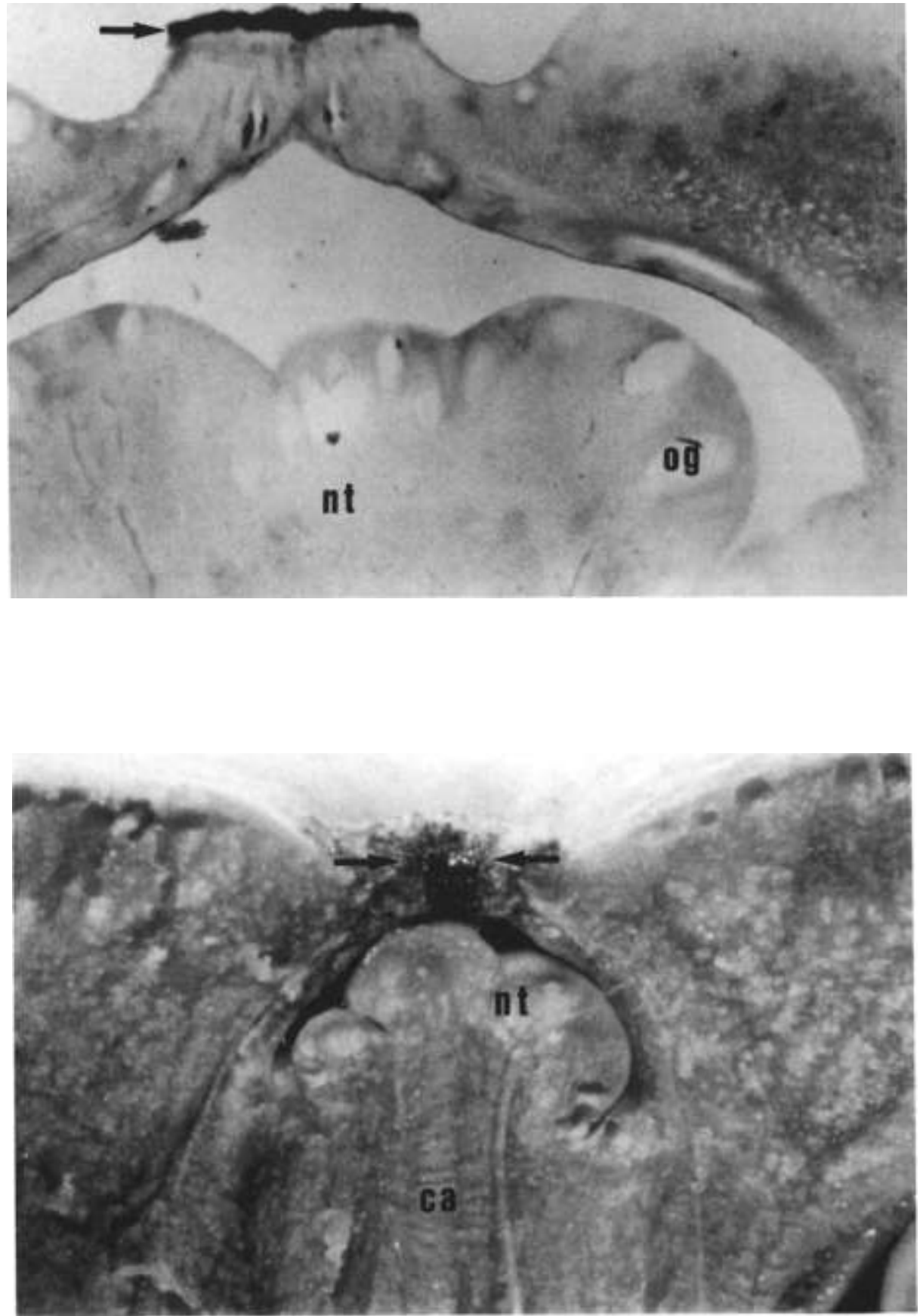


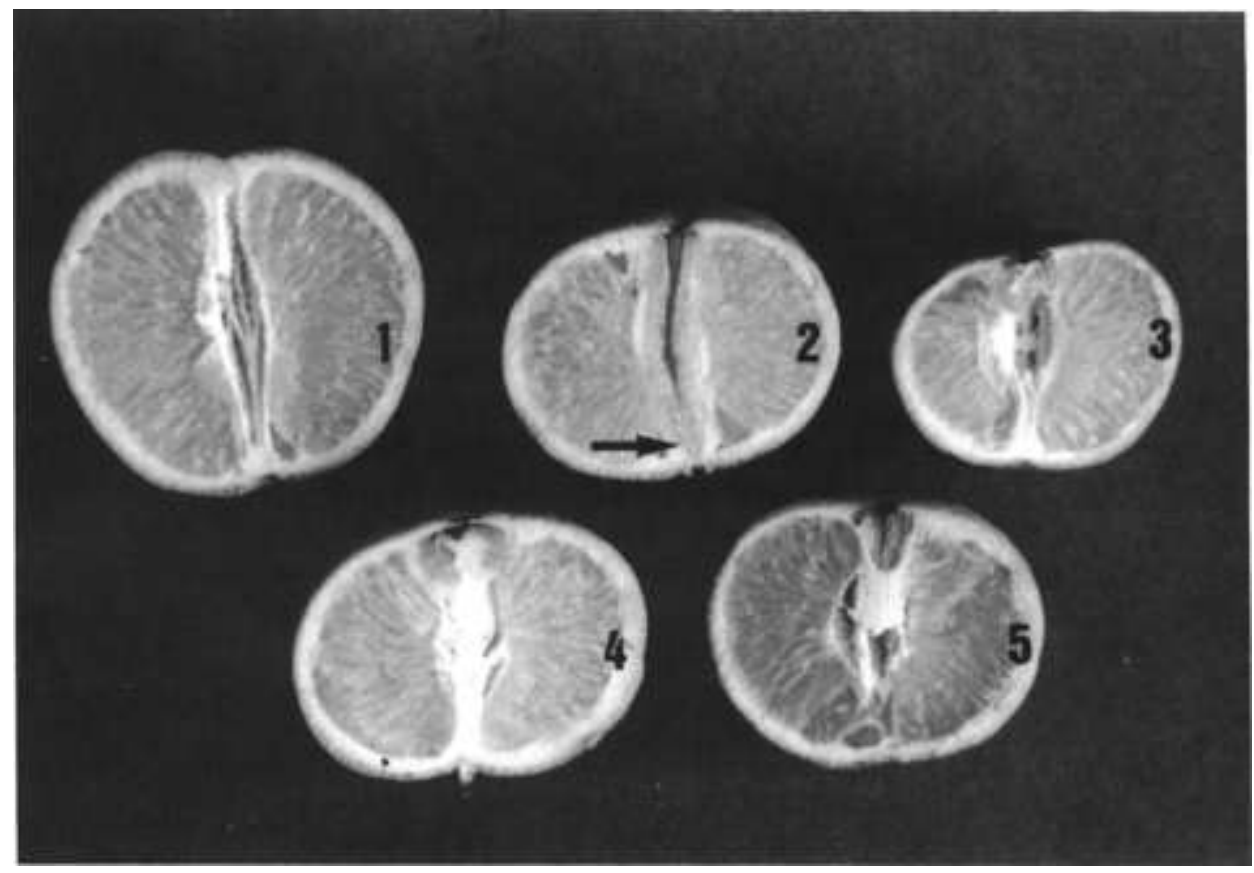

Fig. 5. Aspect of the navel tissue in fruits surviving to maturity (17 January). In fruits with a closed stylar scar (1) the navel tissue is usually of a smaller size than in fruits with a stylar end aperture (2-5 ). In a few cases (2), this navel tissue proliferates deep inside the fruit, eventually reaching the calyx end (arrow).

\subsection{The effect of calcium nitrate sprays on splitting}

Under the conditions of our experiments the calcium nitrate sprays failed to affect either set or splitting. The number of split fruit per tree in the Castellón 1991 experiment was $74- \pm 7$ for the no calcium added treatment, and $76+5$ for the mean of the two calcium added treatments. The corresponding values for the Castellón 1992 experiment were $101+6$ and $108 \pm 6$.

Fig. 4. (A) Longitudinal section of the stylar end from a developing fruitlet shortly after style abscission, showing the suberification of the style scar (arrow) and the proliferation of the navel tissue (nt) inside the cavity. This tissue shows conspicuous oil glands (og) and an exocarp-like structure. (B) Freehand section of the stylar end from a $15 \mathrm{~mm}$ diameter fruitlet showing an open stylar end with a ring of suberised tissue (arrows). The navel tissue (nt), which develops as an outgrowth at the apex of the central axis (ca) of the fruitlet, already fills the stylar cavity completely and is pressing against neighbouring tissues. 


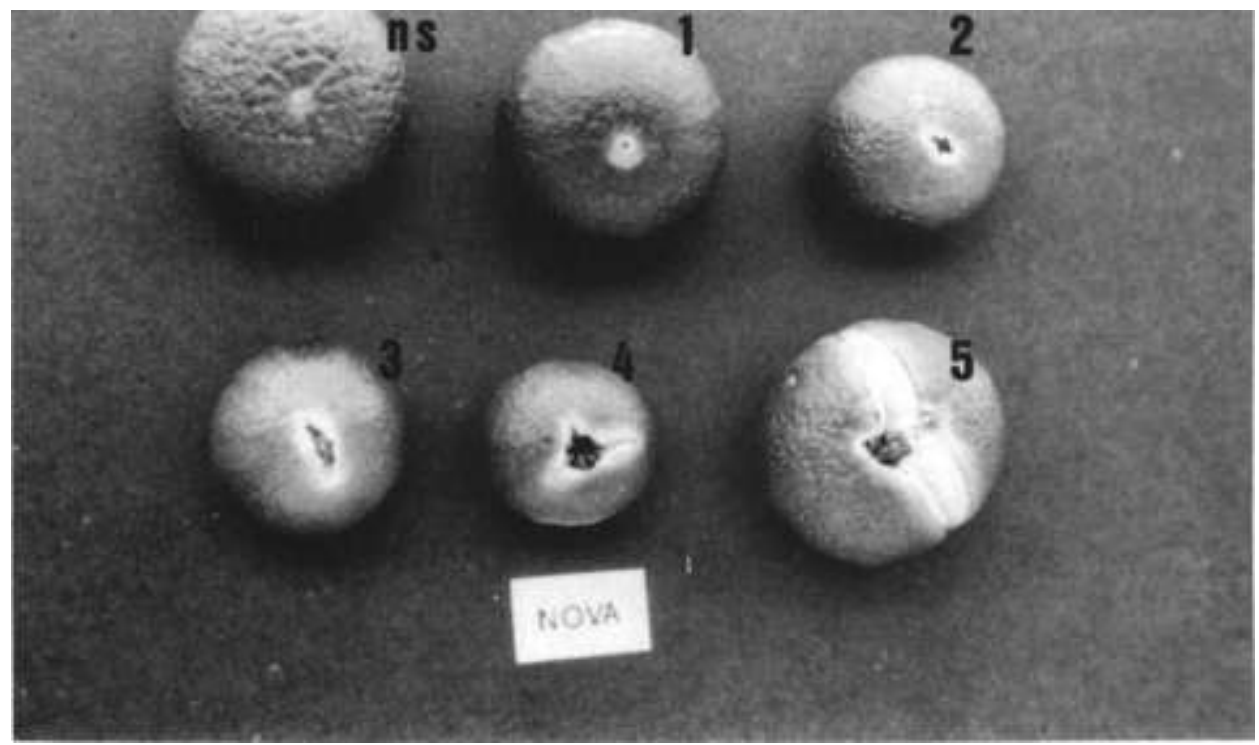

Fig. 6. Successive stages of fruit splitting (1-5) showing the initial discoloration around the stylar end scar followed by the development of the cracks. A non-splitting fruit is also shown (ns). Photograph taken on 8 August.

Table 3

Anatomical characteristics of split compared with non-split fruits on two sampling dates. Data from the Castellón 1992 experiment

\begin{tabular}{|c|c|c|c|c|}
\hline \multirow[t]{2}{*}{ Fruit type } & \multirow{2}{*}{$\begin{array}{l}\text { Fruit diameter } \\
(\mathrm{mm})\end{array}$} & \multicolumn{2}{|c|}{ Stylar end aperture } & \multirow{2}{*}{$\begin{array}{l}\text { Navel } \\
\text { width } \\
(\mathrm{mm})\end{array}$} \\
\hline & & $\%$ Fruits & Diameter $(\mathrm{mm})$ & \\
\hline \multicolumn{5}{|l|}{ October 14} \\
\hline Non-split fruit & $51.1+0.7$ & 8 & $3.6 \pm 0.3$ & $5.6+0.3$ \\
\hline Split fruit & & 86 & & \\
\hline Non-senescent navel & $50.5+0.9$ & 83 & $6.2 \pm 0.5$ & $8.0 \pm 0.6$ \\
\hline Senescent navel & $51.4 \pm 1.0$ & 88 & $4.8+0.3$ & $5.9 \pm 0.3$ \\
\hline \multicolumn{5}{|l|}{ January 15 (at harvest) } \\
\hline Non-split fruit & & 7 & & \\
\hline With stylar end aperture & $60.9 \pm 0.8$ & 100 & $3.8 \pm 0.5$ & $7.0 \pm 0.6$ \\
\hline Without stylar end aperture & $61.5+0.6$ & o & - & $5.6+0.2$ \\
\hline Split fruit & $61.7 \pm \mathrm{L} 8$ & 100 & $4.3 \pm 0.3$ & $7.1 \pm 0.6$ \\
\hline
\end{tabular}




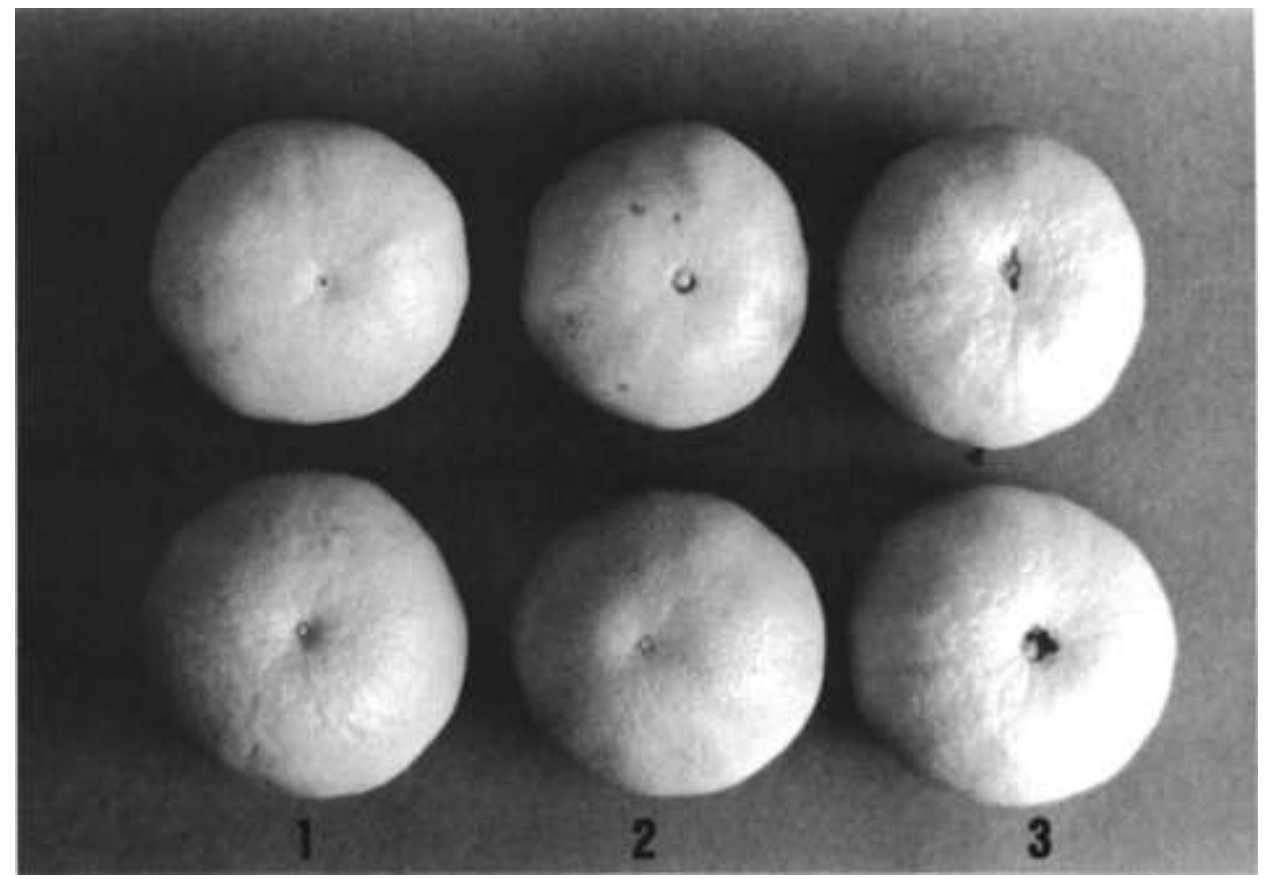

Fig. 7. External aspect of the stylar scar in the fruits reaching maturity. Most of the surviving fruits have a closed scar of small to medium size (1). A small proportion of fruits (about 10\%) have an open stylar end which shows the navel tissue (2). Some of these fruits (3) have small cracks.

Table 4

The effect of hormone applications at full bloom on fruit set and splitting

\begin{tabular}{|c|c|c|c|c|}
\hline Hormone treatment & $\begin{array}{l}\text { Fruit set } \\
\text { (no. per tree) }\end{array}$ & $\begin{array}{l}\text { Split fruit } \\
\text { (no. per tree) }\end{array}$ & $\begin{array}{l}\text { Fruit harvested } \\
\text { (no. per tree) }\end{array}$ & $\begin{array}{l}\text { Percentage } \\
\text { splitting }\end{array}$ \\
\hline \multicolumn{5}{|l|}{ Castellón 1991} \\
\hline Untreated (controls) & 532 & 70 & 462 & 13.7 \\
\hline $\mathrm{GA}_{3}\left(10 \mathrm{mg} 1-^{1}\right)$ & 550 & 92 & 459 & 17.1 \\
\hline $\mathrm{BA}\left(20 \mathrm{mg}^{1-1}\right)$ & 532 & 73 & 459 & 12.9 \\
\hline \multicolumn{5}{|l|}{$\mathrm{GA}_{3}\left(10 \mathrm{mg} 1^{\prime}\right)+$} \\
\hline $\mathrm{BA}\left(20 \mathrm{mg} 1-^{1}\right)$ & 516 & 66 & 450 & 13.1 \\
\hline $\operatorname{SE}(n=9)$ & 32 & 8 & 29 & 1.6 \\
\hline Significance' & NS & $P=0.80$ & NS & NS \\
\hline \multicolumn{5}{|l|}{ Castellón 1992} \\
\hline Untreated (controls) & 837 & 94 & 743 & 11.4 \\
\hline $\mathrm{GA}_{3}\left(10 \mathrm{mg} 1-^{1}\right)$ & 825 & 115 & 710 & 14.1 \\
\hline $\operatorname{SE}(n=32)$ & 24 & 6 & 24 & 0.8 \\
\hline Significance' & $\mathrm{NS}$ & $P=0.95$ & NS & $P=0.95$ \\
\hline
\end{tabular}

'Determined from a full analysis of variance; NS, not significant. 
Table 5

The effect of $\mathrm{GA}_{3}(10 \mathrm{mg} 1$ - ) applications during the summer on fruit set and splitting. Data from the Castellón 1992 experiment

\begin{tabular}{lllll}
\hline $\begin{array}{l}\text { Hormone } \\
\text { treatment }\end{array}$ & $\begin{array}{l}\text { Fruit set } \\
\text { (no. per tree) }\end{array}$ & $\begin{array}{l}\text { Split fruit } \\
\text { (no. per tree) }\end{array}$ & $\begin{array}{l}\text { Percentage } \\
\text { splitting }\end{array}$ & $\begin{array}{l}\text { Fruit harvested } \\
\text { (no per tree) }\end{array}$ \\
\hline None & $832 \mathrm{ab}$ & $119^{\prime}$ & $14.6^{\prime}$ & $713 \mathrm{ab}$ \\
12 June & 896 & $123^{\prime}$ & $13.9^{\prime}$ & $773^{\prime}$ \\
23 July & $836^{\prime}$ & $85 \mathrm{~b}$ & $10.5^{\prime \prime}$ & $751 . . \mathrm{b}$ \\
12 June+ 23 July & $761^{\prime \prime}$ & $91 \mathrm{~b}$ & $12.1^{\prime \prime}$ & $670^{\prime \prime}$ \\
SE (n=16) & 33 & 9 & 1.1 & 34 \\
Significance' & $P=0.95$ & $\mathrm{P}=0.99$ & $P=0.94$ & $P=0.84$ \\
\hline
\end{tabular}

'Determined from a full analysis of variance. Mean separations were performed using the least significant difference test.

\section{Discussion}

During the main period of fruit growth the pressure exerted by the growth of the juice vesicles stretches the albedo layer (mesocarp ), whose cells enlarge tangentially (Bain, 1958; Guardiola and Lázaro, 1987). The cells in the flavedo (outer epidermis) do not increase in size. Instead they keep dividing until fruit maturity, providing the necessary increase in surface area to accommodate a continuously increasing pulp volume. Failure to divide at the appropriate rate causes an increase in strain which eventually leads to tissue failure and splitting.

Epidermal cell division does not occur at the stylar scar, whose cells are heavily suberised. When the stylar scar is small and located at the extreme of the longitudinal axis of the fruit this circumstance does not result in strain, since this point of the fruit does not enlarge. However, when the scar is located away from this point, as is caused by the existence of a stylar end aperture, these non-dividing cells are subjected to increasing strain as the fruit grows. The strains in the longitudinal direction of the fruit should be reduced by the proliferation of the nearby non-suberised cells. In the transverse direction, the suberised cells form a ring of inextensible tissue which may finally break. This explains why the fracture occurs longitudinally opposite to the direction expected from theoretical considerations; as our fruit is an oblate spheroid, the physical stress caused by the enlarging pulp is bigger in the longitudinal direction of the fruit, and this circumstance should lead to a circumferential type of fracture (Considine and Brown, 1981). Local stresses caused by the proliferation of the navel tissue may also contribute to this tissue failure. These two circumstances may explain the relation we found between stylar end aperture and the size of the navel tissue with fruit splitting. Lima et al. (1980) also reported that splitting in 'Washington' navel orange is greatest on fruit with a large stylar end aperture.

In addition to the effect of these two factors, we found that in some fruits splitting was associated with the senescence of the navel tissue (Table 3). This senescence is accompanied by an increase in ethylene synthesis (Lima and Davies, $1984 \mathrm{~b}$ ), which in turn causes the senescence of the epidermal tissue around the 
stylar scar. As a result, cell division ceases and this tissue becomes inelastic and prone to splitting. Chlorophyll loss around the stylar scar is usually the first symptom of splitting (Fig. 6).

Among the hormone treatments we tried, only the $\mathrm{GA}_{3}$ applications had significant effects on fruit set and/or splitting. The response was markedly determined by the timing of the application.

The failure of full bloom or petal fall applications of $\mathrm{GA}_{3}$ to increase set contrasts with the marked increase in set obtained by Goren et al. (1992) with the same cultivar. This different response may be due to the much higher concentration of $\mathrm{GA}_{3}$ used by these authors $(50 \mathrm{mg} \mathrm{1-}$ ) or to the differences in natural (non-induced hormonally) parthenocarpic fruit set among the orchards, a factor which strongly determines the response to $\mathrm{GA}_{3}$ sprays (Fomes et al., 1992). These applications resulted in an increase in splitting as reported by others (Lima and Davies, 1984a; Rabe et al., 1990; Goren et al., 1992). This increase in splitting has been related to the fruit load of the tree and the enhanced competition among developing fruits (Rabe et al., 1990; Goren et al., 1992). This does not seem to be the reason in our work, as splitting was unrelated to fruit load (Fig. 1). Rather, we favour the view that the marked pericarp proliferation caused by the GA3 applications at full bloom (Guardiola et al., 1993) may have resulted in an increase in the size of the navel tissue, a factor linked to splitting.

Post bloom $\mathrm{GA}_{3}$ applications acted in different processes, according to the date of application. When applied in early June, 6 weeks after full bloom, they resulted in an increase in set without concurrent increases in splitting, a response reported previously for 'Washington' navel orange (Lima and Davies, 1984a) and 'Ellendale' mandarin (Rabe et al., 1990). The reason why $\mathrm{GA}_{3}$ increased set at this moment but failed to do so at full bloom was not investigated. At a later date (12 weeks after full bloom), when the fruit was 30 ram in diameter, $\mathrm{GA}_{3}$ reduced splitting, a response which may be related to the capacity of this hormone to block the ethylene-induced senescence of citrus rind (Goldschmidt et al., 1977; GarciaLuis et al., 1986). This change in the response, which is critically time-dependent, may account for the often conflicting literature reports on the effectiveness of $\mathrm{GA}_{3}$ sprays to reduce splitting. These sprays have been reported to be ineffective (Goren et al., 1992) or to have a highly variable effect (Lima and Davies, 1984a; Almela et al., 1992).

From the reduction in splitting obtained with the July $\mathrm{GA}_{3}$ application, an increase in final yield may be expected. The increase in the number of fruit harvested, however, did not reach statistical significance, as the variability in fruit set among trees was of the same order as the reduction in splitting (Table 5). The same problem was encountered with the June $\mathrm{GA}_{3}$ applications. However, the differences in the number of fruit harvested between the trees receiving a GA3 post-bloom spray and the untreated controls are important enough $(8.5 \%$ of the actual crop; $P>0.85$ ) to consider the economic feasibility of these applications. 


\section{Acknowledgements}

This research was supported by a grant from Consejeria de Agricultura y Pesca de la Región de Murcia. Thanks are due to M. Sánchez-Perales for technical assistance, and to Joaquin Llusar and Antonio Lorenzo (TEASA, Murcia) for providing the orchard facilities. A.M.M. Duarte was the recipient of a scholarship from the Programa CIENCIA-Junta Nacional de Investigação Cientifica e Tecnológica (JNICT ) of Portugal.

\section{References}

Almela, V., Zaragoza, S., Agusti, M. and Primo-Milo, E., 1992. Estudio del rajado del fruto de la mandarina Nova y su control. Levante Agric., 320: 144-150.

Bain, J.M., 1958. Morphological, anatomical and physiological changes in the developing fruit of the Valencia orange, Citrus sinensis (L.) Osbeck. Aust. J. Bot., 6: 1-28.

Bar-Akiva, A., 1975. Effect of potassium nutrition on fruit splitting in 'Valencia' orange. J. Hortic. Sci., 50: 85-89.

Considine, J. and Brown, K., 1981. Theoretical analysis of distribution of surface growth forces in fruit in relation to cracking and splitting. Plant Physiol., 68: 371-376.

De Cicco, V., Intrigliolo, F., Ippolito, A., Vanadia, S. and Guiffrida, A., 1988. Factors in Navelina orange splitting. Proc. IM. Soc. Citricult., 1: 535-540.

Erickson, L.C., 1968. The general physiology of citrus. In: W. Reuther, L.D. Batchelor and H.J. Webber (Editors), The Citrus Industry, Vol. II. University of California, Berkeley, pp. 86-126.

Fomes, F., van Rensburg, P.J.J., Sánchez-Perales, M. and Guardiola, J.L., 1992. Fruit setting treatments' effect on two Clementine mandarin cultivars. Proc. IM. Soc. Citricult., in press. Garcia-Luis,

A., Fomes, F. and Guardiola, J.L., 1986. Effects of gibberellin A3 and cytokinins on natural and post-harvest, ethylene-induced pigmentation of Satsuma mandarin peel. Physiol. Plant., 68: 271-274.

Goldschmidt, E.E., Aharoni, Y., Eilati, S.K., Riov, J.W. and Monselise, S.P., 1977. Differential counteraction of ethylene effects by gibberellin A3 and N6-benzyladenine in senescing citrus peel. Plant Physiol., 59: 193-195.

Goldschmidt, E.E., Rabber, D. and Galili, D., 1992. Fruit splitting in 'Murcott' tangerines: control by reduced water supply. Proc. Int. Soc. Citricult., in press.

Goren, R., Huberman, M. and Riov, J., 1992. Effects of gibberellin and girdling on the yield of 'Nova' (Clementine x Orlando Tangelo) and Viva' (Valencia x Wilking ). Proc. Int. Soc. Citricult., in press.

Guardiola, J.L. and Lázaro, E., 1987. The effect of synthetic auxins on fruit growth and anatomical development in 'Satsuma' mandarin. Sci. Hortic., 31: 119-130.

Guardiola, J.L., Barrés, M.T., Albert, C. and Garcia-Luis, A., 1993. Effects of exogenous growth regulators on fruit development in Citrus unshiu. Ann. Bot., 71: 169-176.

Johansen, D.A., 1940. Plant Microtechnique. McGraw-Hill, New York, p. 96.

Lima, J.E.O. and Davies, F.S., 1984a. Growth regulators, fruit drop, yield, and quality of navel orange in Florida. J. Am. Soc. Hortic. Sci., 109: 81-84.

Lima, J.E.O. and Davies, F.S., 1984b. Ethylene, cellulase, 2,4-D, and summer fruit drop of navel orange in Florida. J. Am. Soc. Hortic. Sci., 109: 100-104.

Lima, J.E.O. and Davies, F.S., 1984c. Fruit morphology and drop of navel oranges in Florida. HortScience, 19: 262-263.

Lima, J.E.O., Davies, F.S. and Krezdom, A.H., 1980. Factors associated with excessive fruit drop of navel orange. J. Am. Soc. Hortic. Sci., 105: 902-906. 
Monselise, S.P., Costo, J. and Galili, D., 1986. Additional experiments to reduce the incidence of citrus fruit splitting by 2,4-D and calcium. Alon Hanotea, 40: 1237-1238.

Rabe, E, van Rensburg, P., van der Walt, H. and Bower, J., 1990. Factors influencing preharvest fruit splitting in Ellendale ( C. reticulata). HortScience, 25: 1135 (Abstr. 511).

Ruiz, Ll. and Primo Millo, E., 1989. El rajado, agrieta.do o 'splitting' de los frutos cítricos. Levante Agric., 291: 98-102. 